\title{
Role of hemagglutinin esterase protein in neurological manifestation of COVID-19
}

\author{
Milad Zandi ${ }^{*} \mathbb{B}$, Hassan Karami and Saber Soltani
}

Dear editor,

We read with interest an article by McQuaid et al. [1], in this article, the authors stated that "The lipid plasma membrane has structural proteins, namely the spike protein $(\mathrm{SP})$, membrane protein, small membrane protein and hemagglutinin-esterase" [1]. For this claim, the authors cited a related study, but there is not any evidence on hemagglutinin-esterase gene in that cited reference [2]. However, according to the scientific evidence the genome of SARS-CoV-2 lacks the hemagglutininesterase (HE) gene and it has no HE glycoprotein [3-6], thus HE has no role in neurological manifestation of COVID-19.

From the emergence of SARS-CoV-2 in December 2019, a great amount of efforts and research have been made to characterize the virus and the clinical course of coronavirus disease 2019 (COVID-19) [7]. SARS-CoV-2 as an enveloped, positive-strand RNA virus is a member of Coronaviridae family in Nidovirales order [8]. According the genetic properties Coronaviridae family is subdivided to 4 genera including: alpha, beta, gamma and deltacoronavirus [9]. In addition, betacoronavirus genus has five subgenera: Embecovirus (lineage A), Sarbecovirus (lineage B), Merbecovirus (lineage C), Nobecovirus (lineage D) and Hibecovirus [10].

Between human coronaviruses, OC43-CoV and HKU1$\mathrm{CoV}$ are considered as betacoronaviruses of linage $\mathrm{A}$, however, both SARS-CoV and SARS-CoV-2 are betacoronaviruses of linage $\mathrm{B}$ and also MERS- $\mathrm{CoV}$ is a member of betacoronavirus of C lineage [11].

*Correspondence: Miladzandi416@gmail.com

Department of Virology, School of Public Health, Tehran University

of Medical Sciences, Tehran, Iran
Between coronaviruses, betacoronaviruses lineage A including: bovine- $\mathrm{CoV}$, OC43-CoV, HKU1-CoV, mouse hepatitis virus(MHV), harbor $\mathrm{HE}$ which acts functionally like spike (S) protein $[12,13]$. The gene of HE is transmitted from influenza virus $C / D$ to betacoronavirus lineage A progenitor via horizontal gene as 9-O-Ac-SA-specific hemagglutinin-esterase-fusion (HEF) [11]. The HE in betacoronaviruses lineage $\mathrm{A}$ does not show activity of membrane fusion unlike HEF in influenza virus C/D [11]. SARS-CoV-2 as a betacoronavirus of Sarbecovirus subgenus comprises four structural proteins spike (S), envelope $(\mathrm{E})$, membrane protein $(\mathrm{M})$, and nucleoprotein $(\mathrm{N})$ and lacks HE [6].

In conclusion, $\mathrm{HE}$ gene is absent in betacoronaviruses such as SARS-CoV-2, MERS-CoV and SARS-CoV, thus HE has no role in neurological manifestation of COVID19, however, some betacoronaviruses in subgenera Embecovirus have HE.

\section{Abbreviations}

COVID-19: Coronavirus Disease 2019; SARS-CoV: Severe acute respiratory syndrome-CoV; SARS-CoV-2: Severe acute respiratory syndrome-CoV-2; MERSCoV: Middle East Respiratory Syndrome CoV.

\section{Acknowledgements \\ Not applicable.}

\section{Author contributions}

MZ, Design, wrote; HK and SS involved in investigation. All authors have read and approved the final manuscript.

\section{Funding}

No funding.

\section{Availability of data and materials} Not applicable.

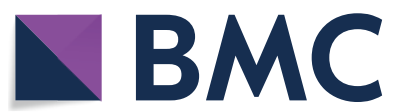

(c) The Author(s) 2021. Open Access This article is licensed under a Creative Commons Attribution 4.0 International License, which permits use, sharing, adaptation, distribution and reproduction in any medium or format, as long as you give appropriate credit to the original author(s) and the source, provide a link to the Creative Commons licence, and indicate if changes were made. The images or other third party material in this article are included in the article's Creative Commons licence, unless indicated otherwise in a credit line to the material. If material is not included in the article's Creative Commons licence and your intended use is not permitted by statutory regulation or exceeds the permitted use, you will need to obtain permission directly from the copyright holder. To view a copy of this licence, visit http://creativecommons.org/licenses/by/4.0/. The Creative Commons Public Domain Dedication waiver (http://creativeco mmons.org/publicdomain/zero/1.0/) applies to the data made available in this article, unless otherwise stated in a credit line to the data. 


\section{Declarations}

Ethics approval and constent to participate

Not applicable.

\section{Consent for publication}

Not applicable.

\section{Conflict of interest}

The authors declare no conflict of interests.

Received: 29 July 2021 Accepted: 5 August 2021

Published online: 16 August 2021

\section{References}

1. MCQuaid C, Brady M, Deane R. SARS-CoV-2 is there neuroinvasion? Fluids Barriers CNS. 2021;18(1):1-21.

2. Das G, Mukherjee N, Ghosh S. Neurological insights of COVID-19 pandemic. ACS Chem Neurosci. 2020;11(9):1206-9.

3. Kumar S, Nyodu R, Maurya VK, Saxena SK. Morphology, genome organization, replication, and pathogenesis of severe acute respiratory syndrome coronavirus 2 (SARS-CoV-2) 2019 (COVID-19). Coronavirus Dis. 2020;23:24.

4. Zandi M, Soltani S. Hemagglutinin-esterase cannot be considered as a candidate for designing drug against COVID-19. Mol Divers. 2021. https:// doi.org/10.1007/s11030-021-10272-w.

5. Devasena T. The Nanotechnology-COVID-19 interface. Gateway East: Springer; 2021. p. 31-58.
6. Zandi M, Soltani S, Feyzi K. SARS-CoV-2 as a betacoronavirus comprises five structural proteins? Infect Genet Evol. 2021. https://doi.org/10.1016/j. meegid.2021.105011.

7. Park SE. Epidemiology, virology, and clinical features of severe acute respiratory syndrome-coronavirus-2 (SARS-CoV-2; Coronavirus Disease-19). Clin Exp Pediatr. 2020;63(4):119.

8. Khailany RA, Safdar M, Ozaslan M. Genomic characterization of a novel SARS-CoV-2. Gene Rep. 2020;19:100682.

9. El-Sayed A, Kamel M. Coronaviruses in humans and animals: the role of bats in viral evolution. Environ Sci Pollut Res. 2021. https://doi.org/10. 1007/s11356-021-12553-1.

10. Li X, Luk HK, Lau SK, Woo PC. Human coronaviruses: general features. Ref Modul Biomed Sci. 2019. https://doi.org/10.1016/B978-0-12-801238-3. 95704-0.

11. Kim C-H. SARS-CoV-2 evolutionary adaptation toward host entry and recognition of receptor O-Acetyl sialylation in virus-host interaction. Int 」 Mol Sci. 2020;21(12):4549

12. Lang Y, Li W, Li Z, Koerhuis D, Van Den Burg AC, Rozemuller E, et al. Coronavirus hemagglutinin-esterase and spike proteins coevolve for functional balance and optimal virion avidity. Proc Natl Acad Sci USA. 2020;117(41):25759-70.

13. Soltani $\mathrm{S}$. The hemagglutinin-esterase gene in human coronaviruses SARS-CoV-2, HKU1 and OC43. Eur Rev Med Pharmacol Sci. 2020;24(12):6484-5

\section{Publisher's Note}

Springer Nature remains neutral with regard to jurisdictional claims in published maps and institutional affiliations.
Ready to submit your research? Choose BMC and benefit from:

- fast, convenient online submission

- thorough peer review by experienced researchers in your field

- rapid publication on acceptance

- support for research data, including large and complex data types

- gold Open Access which fosters wider collaboration and increased citations

- maximum visibility for your research: over $100 \mathrm{M}$ website views per year

At BMC, research is always in progress.

Learn more biomedcentral.com/submissions 